Meta

Journal des traducteurs

Translators' Journal

\title{
Censorship and Digital Games Localisation in China
}

\section{Xiaochun Zhang}

Volume 57, numéro 2, juin 2012

La manipulation de la traduction audiovisuelle

The Manipulation of Audiovisual Translation

URI : https://id.erudit.org/iderudit/1013949ar

DOI : https://doi.org/10.7202/1013949ar

Aller au sommaire du numéro

Éditeur(s)

Les Presses de l’Université de Montréal

ISSN

0026-0452 (imprimé)

1492-1421 (numérique)

Découvrir la revue

Citer cet article

Zhang, X. (2012). Censorship and Digital Games Localisation in China. Meta, 57(2), 338-350. https://doi.org/10.7202/1013949ar

\section{Résumé de l'article}

$\mathrm{Au}$ cours des dernières années, les interrelations entre censure et traduction ont fortement attiré l'attention des chercheurs universitaires qui leur ont consacré de nombreuses recherches. Toutefois, les systèmes de censure et leur influence sur la traduction audiovisuelle, principalement sur la localisation de jeux électroniques, n’ont pas encore été analysés en profondeur d'un point de vue traductologique. Le présent article vise à combler cette lacune par l'examen des opérations de censure menées sur les jeux électroniques dans le contexte socioculturel de la Chine continentale. Il présentera le système de censure chinois, en mettant l'accent sur les autorités de censure, leurs méthodes et leurs procédures, ainsi que les normes et les réglementations en matière de contenu des jeux. Il examinera ensuite l'étendue de l'influence de la censure sur la localisation des jeux dans la pratique et conclura que les professionnels de la localisation tendent à opter pour une rigoureuse autocensure lorsque le système de censure manque de transparence.
Ce document est protégé par la loi sur le droit d'auteur. L'utilisation des services d’Érudit (y compris la reproduction) est assujettie à sa politique d'utilisation que vous pouvez consulter en ligne.

https://apropos.erudit.org/fr/usagers/politique-dutilisation/ 


\title{
Censorship and Digital Games Localisation in China
}

\author{
XIAOCH UN ZHANG \\ University of Vienna, Vienna, Austria \\ xiaochun.zhang@univie.ac.at
}

\section{RÉSUMÉ}

Au cours des dernières années, les interrelations entre censure et traduction ont fortement attiré l'attention des chercheurs universitaires qui leur ont consacré de nombreuses recherches. Toutefois, les systèmes de censure et leur influence sur la traduction audiovisuelle, principalement sur la localisation de jeux électroniques, n'ont pas encore été analysés en profondeur d'un point de vue traductologique. Le présent article vise à combler cette lacune par l'examen des opérations de censure menées sur les jeux électroniques dans le contexte socioculturel de la Chine continentale. Il présentera le système de censure chinois, en mettant l'accent sur les autorités de censure, leurs méthodes et leurs procédures, ainsi que les normes et les réglementations en matière de contenu des jeux. Il examinera ensuite l'étendue de l'influence de la censure sur la localisation des jeux dans la pratique et conclura que les professionnels de la localisation tendent à opter pour une rigoureuse autocensure lorsque le système de censure manque de transparence.

\begin{abstract}
Censorship and translation is a topic that has received substantial attention in academic circles in recent years. Although much of the research has focused on the interrelationship between these two areas, censorship systems and their influence on audiovisual translation, especially digital games localisation, has not been fully examined within the scope of translation studies. This article aims to fill that gap by investigating censorial operations on digital games against the socio-cultural background of Mainland China. It will provide an overview of the Chinese censorship system, with a particular focus on the censoring authorities, their reviewing procedures and methods, including the regulations and standards on game content. It questions the extent to which censorship influences games localisation in practice and concludes that game localisers tend to perform stringent self-censorship when the censorship system itself lacks transparency.
\end{abstract}

\section{MOTS-CLÉS/KEYWORDS}

censure, jeux vidéo, jeux électroniques, localisation, Chine

censorship, video games, digital games, localisation, China

\section{Introduction}

The term censorship is generally considered to carry negative connotations, often being linked to dictatorial regimes, propaganda and repression. According to the Oxford English dictionary online, a censor is "an official in some countries whose duty it is to inspect all books, journals, dramatic pieces, etc., before publication, to secure that they shall contain nothing immoral, heretical, or offensive to the government." In particular, this definition seems to suggest that censorship is not a universal phenomenon but exists only "in some countries." However, censorship is surprisingly ubiquitous, as Wolf (2002: 45) has pointed out, and it can be seen to exist 
"in all forms of societal organization." Kuhiwczak (2009: 46) is of the same opinion when he states that "there has never been a society without some form of censorship." Indeed, Billiani (2007a: 3-4) also notes that censorship may be seen in a broader sense as "a form of manipulative rewriting of discourses by one agent or structure over another agent or structure, aiming at filtering the stream of information from one source to another" and the function of censorship is "a filter in the complex process of cross-cultural transfer," which is "encouraged by translations."

Owing to the rapid development of information technology and economic globalisation, translation is no longer simply limited to linguistic and cultural transfer across languages, but also transcends media and other locales. Digital games, also known as interactive entertaining software, represent a new form of media which has developed into a fast-growing industry in recent years. As a global cultural product, digital games cannot merely be viewed as just games. Consciously or unconsciously, culture, ideology and philosophy are embedded in such products. Indeed, the ethics of digital games has been the subject of on-going debate, especially among parents, educators, sociologists, and game designers, where the nature of censorship is said to "define the space it protects" (Ní Chuilleanáin, Ó Cuilleanáin et al. 2009a: 21). Protection of minors is often cited as a major reason for censorship in digital games localisation. Unlike other forms of censorship, such as literature censorship, censorial operations on games conducted by governments have been mostly welcomed and supported by parents, educators and retailers, notwithstanding criticisms that it tramples on basic human rights such as freedom of speech. More specifically, censorship systems on digital games have received much attention from both governments and the general public in order to ensure that any contents that may have potentially harmful effects on the next generation are filtered. The censorship systems also provide guidelines for games localisers to adapt different cultural contents into particular locales.

Although substantial research has been directed to the study of censorship and translation in recent years (Merkle 2002; Billiani 2007b; Seruya 2008; Ní Chuilleanáin, Ó Cuilleanáin et al., 2009b; Merkle, O’Sullivan et al. 2010), censorship systems and their impact on audiovisual translation, especially on games localisation, have not received sufficient attention within the domain of translation studies. This article focuses on censorship systems and their impact on audiovisual translation, with particular reference to the translation of language in the overall process of games localisation. It investigates the censorship mechanism in China, including the relevant censoring authorities, procedures, methods, and standards on game content. It then leads to a discussion of the impact of the censorship system on game localisation in practice.

\section{Censorship System on Digital Games in China}

Censorship "imposed by public authorities by virtue of explicit laws" is defined by Brownlie (2007: 205) as "public censorship" and is the type encountered in China. In her view, it may "occur either prior to the publication of a work, or after its publication [and] most notably in the form of the banning of a work" (Brownlie 2007: 205). In this respect, China has developed a particularly sophisticated public censorship system which applies to all media, including games. Given that the video gaming 
industry in Mainland China has been dominated by online games, contributing $97 \%$ of the revenue income of the whole gaming industry in 2010 (Xinhua Games 2011), ${ }^{1}$ and the censorship system on imported online games is also more complex than other types of games, this section will therefore address the censorship system based on the censorial operations of imported online games.

\subsection{The censoring authorities}

When online games first entered the Chinese market in 2000, there were no specific laws or regulations available to governmental administrators, particularly when dealing with the publication and operation of this new cultural product. Today, the situation is somewhat different, where the supervision and administration of online games is carried out by more than one governmental department, which may be attributed in large part to the different understandings of their departmental responsibilities. The two departments which have played major roles are the General Administration of Press and Publication P. R. China (GAPP; 中华人民共和国新闻 出版总署) and the Ministry of Culture P. R. China (MOC; 中华人民共和国文化部). Perhaps unsurprisingly, the involvement of the two authorities eventually resulted in some overt conflicts. For example, Wrath of Lich King, an add-on expansion for World of Warcraft (Blizzard Entertainment 2004), was withheld until August 2010 while in the process of having its contents reviewed. The final version of the Chinese game was released some 22 months after the European launch date ( $\mathrm{Hu}$ and Wang 2009), ${ }^{2}$ primarily due to outstanding disputes between GAPP and MOC with regard to which of the two bodies should exercise most authority in the process of examination and approval of games.

In an attempt to resolve these regulatory battles, the General Office of the State Council of P. R. China (2008; [中华人民共和国国务院办公厅]) issued The Notice of the General Office of the State Council on Issuing the Provisions on the Main Functions, Internal Bodies and Staffing of the General Administration of Press and Publication (关于印发国家新闻出版总署(国家版权局)主要职责内设机构和人员编制规定的通 知), ${ }^{3}$ referred to as Provisions on Three Determinations (三定” 规定). A year later, the State Commission Office for Public Sector Reform of P. R. China (2009; [中央机构 编制委员会]) issued the Notice on Printing and Distributing the Explanations of the State Commission Office for Public Sector Reform on Some Provisions concerning Cartoons, Online Games and the Comprehensive Law Enforcement in the Cultural Market of the Provisions on Three Determinations regarding the Ministry of Culture, the State Administration of Radio, Film and Television and the General Administration of Press and Publication (中央编办对文化部、广电总局、新闻出版总 署《“三定” 规定》中有关动漫、网络游戏和文化市场综合执法的部分条文的解释〉 的通知), ${ }^{4}$ referred to as the Explanations on Three Determinations (三定” 解释) to specify the functions of GAPP and MOC on online games. According to these two sets of regulations, MOC is the department in charge of the administration of online games and GAPP is responsible for the examination and approval of online games prior to publication, under the general guidance of MOC. After the game has been published online, the supervision and administration shall be carried out by MOC. However, for imported online games, in particular those that are authorised by overseas copyright owners, the process should be governed by GAPP, while the remain- 
ing games are supervised by MOC. In practice, games publishers and operators are requested to have their products registered and reviewed with both authorities.

It is currently standard practice for GAPP to conduct a review of all games prior to their release; whereas, MOC monitors and supervises the operation of games after their publication. Although the functions of these two key players in online games censorship seem to have been recently clarified, it may be argued that the involvement of more than one department could potentially lead to further disputes in the future. Both national and international games localisers therefore tend to be very cautious in their preparation for the review and censorship stages, especially given the complicated situation of having to satisfy two censors and where any delay in the launch date may cause serious economic losses in the games market.

\subsection{The reviewing procedures and methods}

As mentioned above, the censorship of online games in China occurs both before and after publication. With regard to examination and approval prior to publication, Kou Xiaowei, vice director of the technology and digital publishing division of GAPP explains that the process involves two aspects: first, an inspection on the business qualification of the operating enterprise, which concerns whether a game company is competent to operate and regulate its business scope; and secondly, a review of the content of online game to examine its suitability for publication (Luo 2009). ${ }^{5}$ If the outcome is positive, the games operator then becomes qualified and is issued with "one license and three numbers" (Li 2010). ${ }^{6}$ The license refers to the Internet Publishing Services License (互联网出版服务许可证), regulated by a circular (GAPP - State Copyright Administration and National Anti-Piracy and Pornography Working Group Office of P. R. China 2009), ${ }^{7}$ which permits the right of a company to publish electronic products on the Internet. The three numbers indicate: 1) the reference number from the authentication of a commercial contract with game export company and the contract on copyright; 2) the approval number of the game content inspection; 3) the ISBN number.

As seen from above, beyond the business qualification of the game companies, the game content is also subject to stringent examination which is defined by certain strict procedures and regulations. Before publication, the following materials are required by GAPP $(2010)^{8}$ for examination and approval:

1) Application form for publishing imported online gaming products;

2) the Registration Certificate of Copyright Contact (著作权合同备案证书) issued by copyright contract registration institutes;

3) full Chinese script of the online gaming products;

4) colour printed pictures and demonstration discs, which indicate the main characters, scenes, tools, storylines, function settings and the general features of the products;

5) three sets of administrator accounts and user clients, which can be used to perform censorship;

6) opinions from the publishing institutes.

In addition to the above-mentioned inspection procedure, game producers are also urged to incorporate an anti-addiction system to all games, which was introduced by GAPP and seven other national authorities in 2007 . The online game anti-addiction 
system aims to prevent people under the age of eighteen in China from playing online games non-stop for too long. According to the Online Game Anti-addiction System Development Standard (GAPP 2007), ${ }^{9}$ game benefits, such as experience points, virtual money, and equipment gained in games, will be deducted when a minor continuously stays in a game beyond three hours. To ensure its effective implementation, on 1 July 2011, GAPP, together with other governmental departments and associations, launched a real-name authentication system that requires game players to link their real name and ID number to their game account to prove their age. The system was officially in effect as of 1 October 2011 (GAPP 2011). ${ }^{10}$

As cultural products, online games require an Internet Cultural Operation License (网络文化经营许可证) from the MOC (2011), ${ }^{11}$ who provide authorisation for game operators to run online games. The materials requested by MOC $(2006)^{12}$ in the process of reviewing game content differ from those required by GAPP, and include the following:

1) the declaration form for the content censorship of imported online games products and the material registration form for imported online games products;

2) the prospectus explaining the general theme and content of the game;

3) the product operating instructions, both in Chinese and in the original foreign language;

4) three copies of sample game products (texts in Chinese and foreign languages, including the online games software client program, in CD-ROM or DVD format), as well as the account numbers and passwords, allowing access to the highest administrative level (or at the top game level);

5) the full dialogue as well as narrations, descriptive texts and the lyrics of all the songs used in the game, both in Chinese and in the foreign language;

6) either the product copyright business agreement or the operating agency agreement in Chinese and in the foreign language;

7) the original copyright certificate;

8) the original or a photocopy of the copyright authorisation certificate;

9) the rating evaluation certificate or any other relevant certificate on the game product that has been issued in the exporting country;

10) photocopies of both the Internet cultural operation license and the business license of the applicant company;

11) the result of the self-examination by the game operators, including any relevant comments about the content that may be a cause for dispute;

12) any other documents that may be needed for the content censorship.

In contrast to GAPP, MOC places greater emphasis on the linguistic aspects of a game. All the dialogue exchanges, narrations, descriptive texts, the lyrics of theme songs and interlude songs are requested for examination, not only in Chinese but also in the original language so that they can be compared. It is also noteworthy that MOC requires game operators to carry out a process of self-censorship on the contents of their games before submitting them to MOC. A report on the selfexamination outcome has to be presented to MOC. In order to understand the broader context of self-examination in games localisation, it is necessary to consider the way in which translators in China resort to self-censorship, a topic discussed later in this article.

The process and methods followed in the censorship of the content of the online games have not been officially publicised by the authorities. However, Xin (People's 
Procuratorate of Liangzhong City 2009), ${ }^{13}$ one of the censors who reviewed World of Warcraft, revealed some interesting details in an interview. According to Xin, the examination process is "very simple." He explained that three experts are invited to examine all the components of a game using the account number and password provided by the game producers, which grant them full access to the highest level. However, given that most of the online games are of considerable length, it would take a substantial amount of time to inspect all parts of the game and it is for this reason that, according to Xin, "nobody could have enough time to inspect all the details," adding that the standards and procedures for reviewing games are out-ofdate and suffer from many flaws. He also conceded that not being a game player himself, he does not know everything that needs to be known about games. His frank comments provoked large-scale criticism amongst the game-playing population in China. Many considered it inappropriate to have a game reviewed by three people who, by their own admission, have insufficient knowledge about games, but still are invested with the authority to decide on the influence that a game may have on players of all ages, especially adolescents, and ultimately to decide on whether to approve its release in China or not. The information revealed by Xin has not been publically acknowledged or counter-argued by GAPP or MOC officials, and to date the exact procedures and methods followed in the review of games content still remain unclear to the general public.

In addition to the evaluation prior to the release of the game, MOC has urged the establishment of a post-publication supervision system, which, according to the Circular on Improving and Strengthening Online Games Content Administration (MOC 2010), ${ }^{14}$ should be a comprehensive governance mechanism requiring schools, parents, media and society at large to work closely on supervising game content. The supervision should take account of feedback from the public. Regular checks should be conducted on online games by representatives from the educational and consumer sectors, as well as relevant government officials and professionals from the media and other fields. The results of these evaluations would be expected to be announced to the general public so that they are kept informed. The post-publication stage demonstrates that meeting all the requirements imposed by the censorship authorities is not the end of the censorship process and should any products generate adverse public opinion, they may be subject to re-evaluation.

\subsection{The Regulations on Game Content}

Despite the lack of comprehensive guidelines or regulations focusing on the censorship of games, some general guidance may be identified which is based on the Regulations on Publication Administration. This governs the "publishing, printing or reproduction, importation and distribution of publications [of] newspapers, periodicals, books, audiovisual products, electronic publications, etc." (State Council of P. R. China 2011). ${ }^{15}$ According to Article 3 of the Regulations, all publications

[...] shall persist in the direction of serving the people and socialism, uphold MarxismLeninism, Mao Zedong Thought and Deng Xiaoping Theory and the important thought of 'Three Represents' as its guiding ideology, implement the scientific outlook on development, disseminate and accumulate all the scientific, technological and cultural knowledge that is beneficial to the improvement of national quality, the development 
of the economy and the all-round progress of the society, carry forward the splendid accomplishments of national culture, facilitate international cultural exchanges, enrich and improve the cultural life of the people. (State Council of P. R. China 2011) ) $^{16}$

Further, Article 55 indicates that the State supports and encourages (支持、鼓励) the release and commercialisation of products portraying the following characters:

1) those playing a significant role in the exposition and dissemination of the basic principles established by the Constitution; 2) those developing the socialist core value system, and having great significance in educating the people in patriotism, collectivism, socialism and national unity education, and in developing social morality, professional ethics and family virtue; 3 ) those playing a significant role in the enhancement of the essence of national culture and promotion of the international cultural exchange; 4) those making important contributions to the stimulation of cultural innovation and timely reflection of the latest scientific and cultural achievements both at home and abroad; 5) those making important contributions to serve agriculture, rural areas and farmers, and to promote public cultural service; 6) those with important ideological, scientific, cultural or artistic values. (State Council of P. R. China 2011)17

Significantly, Article 25 offers a reasonably detailed list of the contents that are to be forbidden, which is also quoted in Article 16 in the Interim Provisions on the Administration of Internet Culture (互联网文化管理暂行规定):

1) those opposing the basic principles established in the Constitution; 2) those endangering the unification, sovereignty and territorial integrity of the State; 3) those divulging secrets of the State, harming national security, or impairing the honour and interests of the State; 4) those inciting the enmity, discrimination of nationalities, jeopardizing the unity among the various ethnic groups, or violating the customs and habits of minority nationalities; 5) those spreading cults or superstitions; 6) those disturbing social order and destroying social stability; 7) those inciting pornography, gambling, violence or instigating a crime; 8) those insulting or libelling others, violating the lawful rights and interests of others; or 9) those endangering social moralities or fine national cultural traditions; 10) other contents which are prohibited by laws and administrative regulations or by the State. (MOC 2011) $)^{18}$

Although these Articles do indeed indicate what the government permits and forbids, difficulty may arise from the fact that they are mostly couched in rather vague language. For example, in the Regulations on Publication Administration, the government encourages works that enhance “the essence of national culture” (民族优秀文 化) in Item 3 of Article 55, while in Item 9 of Article 25 it forbids any content that would endanger “social moralities or fine national cultural traditions” (社会公德或 者民族优秀文化传统) (State Council of P. R. China 2011; see note 15). The definition of “social moralities" (社会公德) and what can be considered as “fine” (优秀) or “essence of” (精华) national culture are not specified and any attempts to define such terms are always controversial as they are always based on different understandings and personal subjectivities.

Even though the scope and content of such regulations remain unclear, many games have nevertheless been banned. Most of the games affected have been subsequently blacklisted under Item 7 of Article 25, which forbids the release of "those inciting pornography, gambling, violence or instigating a crime” (宣扬淫秽、奢博、 暴力或者教唆犯罪的) (State Council of P. R. China 2011; see note 15). Pornography and gambling are specifically illegal in China, and the MOC has cracked down on 
many games which feature such content in recent years. For instance, in 2009, MOC (Yangyu 2009) ${ }^{19}$ banned 219 online games for containing pornographic and violent content and, according to Chinese media sources, it mobilised administrative law enforcers to deal with more than 2.9 million people and blocked access to games, such as 红灯中心 [Red Light Center] (2006; Utherverse) and Office 三国 [Office Three Kingdom] (2008; Dang Ai Shi Kong) on around 87 million occasions. MOC (2009) ${ }^{20}$ also made an official announcement, forbidding websites from "running, publishing or providing links to online games that contain mafia-like gangs features," where these games "advocate obscenity, gambling, or violence [and] undermine morality and Chinese traditional culture." According to the circular, several online games, including 教父 [Godfather] and 江湖 [Gangster Community], were taken off websites respectively.

Politics is also another area of particular concern for censors. Games that contain political references, especially those which include territorial issues relating to Taiwan and Tibet - both considered by the government as provinces that are part of P. R. China and not independent territories - seem to be specifically prone to clash with the Chinese authorities. For example, in 2004, according to a report by Sheng and Zhu (2004), MOC banned Hearts of Iron (2002; Paradox Entertainment), a Swedishmade computer game set against the background of World War II from 1936 to 1948. It was banned for "distorting history and damaging China's sovereignty and territorial integrity" (Sheng and Zhu 2004). ${ }^{21} \mathrm{MOC}$ considered that the game misrepresented some historical facts, particularly in its portrayal of the Fascist regimes of Japan, Germany and Italy, where the players may change or witness events different from how they actually occurred. Furthermore, the regions of Manchuria, West Xinjiang, and Tibet were marked as independent sovereign states in the maps of the game set during the 1940s, and Taiwan appeared as a territory belonging to Japan, which was considered to harm China's territorial integrity.

Furthermore, as Zhang (2008) discussed, a Japanese game called Big Stratagem: The History of the Greater East Asia Co-prosperity Sphere II (2005; System Soft/Alpha), was banned by GAPP in 2005 (Zhang 2005). ${ }^{22}$ This game was set against the Pacific front during World War II and allows players to devise various strategies for invading and occupying China step-by-step in a virtual battlefield, by killing Chinese soldiers and carrying out bomb attacks, which was considered promoting Japanese right-wing anti-Chinese nationalism. Presenting Taiwan as an independent country is another controversial aspect of the game, which is against the official foreign policy of P. R. China. Zhang (2008) also noted that these territorial issues are not limited to the domain of war games. For example, the football management simulation game 足球经理 Football Manager (2005; Sports Interactive/Sega) was banned for the inclusion of Chinese Tibet, Hong Kong, and Taiwan in the line-up of available football teams, of equal status to China itself (Sheng and Chen 2005). ${ }^{23}$

The crackdown on illegal games by the authorities has provoked an outcry from both game players and game companies who argue that the censorial guidelines are not sufficiently transparent and its restrictions on game content are too stringent. Given that one of the reasons put forward by the Chinese government to justify censorship has been its concern with protecting minors, some individual gamers, industry insiders and other social groups, such as the Youth Protection Association (青少年保护协会), launched a petition to the authorities in 2004 asking for the 
setting up of an age-rating system, such as Pan European Game Information (PEGI) in Europe and Entertainment Software Rating Board (ESRB) in Canada and the United States. The Chinese Network Association for Young People (中国青少年网络 协会) also brought forward a Green Games Recommendable Regulation (绿色游戏推 荐标准) in the same year establishing that games suitable for players under 18 years old are considered as green games (Tang 2004). ${ }^{24}$ This discussion has been going on for several years now, but it has not been officially recognised and no outcome can be appreciated yet in the industry. In March 2010, the vice director of the Culture Market Department of MOC announced that an age-rating system "will not be built" (不会分级), due to the complexity of the gaming market (Zhang 2010). ${ }^{25}$ Despite the disappointment felt by many adult players and the potential loss of revenue for producers in the games market, the censorship of games in China continues to apply the same parameters irrespective of age groups. On the other side of the coin, many parents and educators have applauded the Government for its decision to ban all games which are believed to have ill effects on minors.

\section{The Impact of the Censorship System on Game Localisation}

The lack of explicit, clear-cut regulations from the authorities with respect to the age-rating of games arguably encourages game localisers to conduct their own selfcensorship. In her discussion of self-censorship, Brownlie (2007: 206) states that it "occurs prior to publication when the cultural agent censors his or her work voluntarily, in order to avoid public censorship, and/or in order to achieve approval from the dominating sector in society." Tymoczko, elaborating on Gambier's (2002: 217) original observations, points out that "the absence of firm directions leaves the translator to his or her own judgment about how to translate, the result often being adaptation to normative pressure" (Tymoczko 2009: 31). In China, the situation is compounded by the fact that self-censorship is not only conducted voluntarily by translators or localisers but is also requested by the authorities.

As mentioned above, MOC requires game producers to perform self-censorship before handing over any materials for content review. In Item 3 of the Circular on Improving and Strengthening the Management of Online Games Content (关于改进 和加强网络游戏内容管理工作的通知), MOC (2010; see note 14) stresses that all online games operators shall establish their own special self-censorship departments to administer the product and examine its content before developing, registering, and operating a game. The operators are also required to organise training on policy and regulation for staff working on game planning, research and development, in order to increase their legal awareness and social responsibility and consciousness. The directors of these self-censorship departments are required to be trained by MOC.

Against the background of opaque guidelines on the censorship of games, and under the potential risk of having a product banned by censors, translators and localisers tend to perform a very strict form of self-censorship. Again, taking the game World of Warcraft (WoW) as an example, a multiplayer online role-playing game set in a fantasy world, where gamers can create and play a character by choosing from 12 races and 10 professions to fulfil various tasks or missions, considerable amendments were made to the game during an update in 2007. As noted in Zhang (2008), rogue was toned down from 盗贼 [thief] in the previous release to 隐形者 
[invisible man]; the activity of stealing was modified into 搜索 [search], and poison was changed into 药膏 [ointment]. Additionally, skeletons became zombie-like creatures, and the bones of dead players were replaced by tombstones. According to staff members from The9, the localiser and operator of WoW at that time, these changes were made because of "China's particular situation and relevant regulations" (Feng and Wang 2007). ${ }^{26}$ Zhao Yurun, director of public relations at The9, acknowledged in an interview with Xinhua News Agency $(2007)^{27}$ that the changes were part of an "operational strategy." He explained that the company updated the game several times each year, adding patches to the original version that did not require governmental approval. However, these modifications laid the foundation for the first official expansion of WoW, The Burning Crusade, during which time its contents were in the process of being reviewed by the GAPP. Significantly, it was hoped that these changes could be recognised as demonstrating self-discipline, so that the expansion would receive the necessary approval.

Another example of self-censorship may be seen in Sid Meier's Civilization IV (2005; Firaxis Games/2T Games) (Zhang, 2008). It is a turn-based strategy game, the storyline of which starts with a settler who builds a single city in $4000 \mathrm{BC}$. The tasks for players are to expand it into an empire by making use of geographical advantages, building social and production infrastructures, making progress on science and culture, and fighting against competing nations. Within the game there are eighteen civilizations each of which has one or two leaders with specific personality traits with extra powers to enhance the probability statistics. A wide variety of historical figures and famous architectural landmarks are featured in the Civilization games, where China is listed among other nations. In particular, Qin-Shi-Huang and Mao Zedong are named as the leaders of China and Beijing is the capital city. In addition, the Great Wall and the Three Gorges Dam are also listed as Wonders of the World. With its numerous references to historical and political elements, the game risked attracting the censors' attention and CEASIA, the publisher of the official simplified Chinese version, performed strict self-censorship before releasing the game in 2007. The localisers rewrote nearly the whole storyline about China in an attempt to keep official censorship forces at bay. Thus, China was changed into an imaginary Jiu-DingKingdom with its capital in the city of Bei City and two leaders named Qin-Gong and Tang-Gong. The background briefing, which functions as an introduction, clearly states that the game is a "fictitious story and does not link it to true historical facts." All references to former communist leader Mao Zedong were erased and The Great Wall and The Three Gorges Dam were replaced by the wonders of the Macedonian Line in Europe and the Hoover Dam in the USA. Interestingly, 'communism' was renamed 'perfectionism,' which may be seen as an overt propaganda strategy to placate censors. It would seem that the modifications represented a clear attempt to detach the game from real historical facts and to dilute any references to Chinese culture and society in order to avoid being accused of misleading young people.

Although none of these two games seem to breach any of the legal requirements laid out in the official regulations, substantial modifications have been made to the games by the game localisers under self-censorship. It is also worth mentioning that these censorship attempts have not always been effective, since gamers can bypass government blocks by using proxy servers, private servers, and accessing pirate games from some online forums. 


\section{Conclusion}

As is apparent from the above discussion, the censorship system on digital games has had a considerable impact on games localisation in China. Not least, there is evidence that the involvement of more than one censoring authority, vague guidelines on the suitability of game content and the lack of transparency in the reviewing process have prompted some game translators and localisers to consider the scale and degree of what is permitted in a subjective manner. In such circumstances, to avoid any potential censorial problems it may be argued that some of the modifications made to the games by game localisers could end up being more stringent than those contemplated by the authorities. As suggested, to ensure its future effectiveness and the smooth running of the game industry, translators and producers are in need of more detailed guidance about the censorship system in China.

\section{NOTES}

1. XINHUA GAMES [新华游戏] (16 March 2011): 游戏工委: 2010年度中国游戏产业调查报告摘要 [Games Working Committee: The 2010 Chinese Gaming Industry Research Report Summary]. Visited on 24 September 2011, <http://news.xinhuanet.com/games/2011-03/16/c_121192749.htm>.

2. Hu, Yinan and WANG, Xing (2009): Battle breaks out over online game WoW. Visited on 24 September 2011,

<http://www.chinadaily.com.cn/business/2009-11/04/content_8909420.htm>.

3. General Office of the State Council of P. R. China [中华人民共和国国务院办公厅] (2008): 关于印 发国家新闻出版总署(国家版权局)主要职责内设机构和人员编制规定的通知 [The Notice of the General Office of the State Council on Issuing the Provisions on the Main Functions, Internal Bodies and Staffing of the General Administration of Press and Publication]. Visited on 24 September 2011, <http://vip.chinalawinfo.com/newlaw2002/slc/slc.asp?db=chl\&gid=109110 $>$.

4. State Commission Office for Public Sector Reform of P. R. China [中央机构编制委员会办公室] (2009): 中央编办对文化部、广电总局、新闻出版总署《“三定” 规定》中有关动漫、网络游戏和文 化市场综合执法的部分条文的解释〉的通知 [Notice on Printing and Distributing the Explanations of the State Commission Office for Public Sector Reform on Some Provisions concerning Cartoons, Online Games and the Comprehensive Law Enforcement in the Cultural Market of the Provisions on "Three Determinations" regarding the Ministry of Culture, the State Administration of Radio, Film and Television and the General Administration of Press and Publication]. Visited on 24 September 2011, <http://www.law-lib.com/law/law_view.asp?id=299231>.

5. LuO, Liang (2009): 版署寇晓伟: 网游前置审批包含两方面审批 [Kou Xiaowei from GAPP: Prior Publication Examination and Approval Includes Two Aspects]. Visited on 24 September 2011, $<$ http://tech.qq.com/a/20091010/000228.htm>.

6. LI, Miao (2010): 新闻出版总署多项措施加强网络游戏监管 [Several Measures from the General Administration of Press and Publication Strengthen the Inspection and Management of Online Games]. Visited on 24 September 2011, <http://www.gapp.gov.cn/cms/html/21/1025/201001/696527. html>.

7. GAPP - State Copyright Administration and National Anti-Piracy and Pornography Working Group Office of P. R. China [新闻出版总署 国家版权局 全国 “扫黄打非” 工作小组办公室] (2009)：关于贯彻落实国务院〈”三定”规定〉和中央编办有关解释, 进一步加强网络游戏前置审 批和进口网络游戏审批管理的通知 [Circular on Implementation of the State Council's Regulation on the Key Responsibilities, Internal Functions and Staffing of the General Office of the State Council and State Commission Office for Public Sector Reform's Relevant Interpretations, and Further Strengthening Pre-approval of Online Game and Administration of Imported Online Game]. Visited on 24 September 2011, <http://china.findlaw.cn/fagui/xz/10/223940.html>.

8. GAPP [中华人民共和国新闻出版总署] (2010)：出版境外著作权人授权的互联网游戏作品审批 申办材料说明 [Explanation on the Application Materials for Inspection and Approval of Publishing Online Games Products Authorized by Foreign Copyright Owner]. General Administration of Press and Publication of P. R. China. Visited on 24 September 2011, <http:// www.gapp.gov.cn/cms/html/21/496/List-1.html>. 
9. GAPP (2007): 网络游戏防沉迷系统开发标准 [Online Game Anti-addiction System Development Standard]. General Administration of Press and Publication of P. R. China. Visited on 24 September 2011, <http://game.people.com.cn/GB/48644/48662/5680982.html>.

10. GAPP (2011): 关于启动网络游戏防沉迷实名验证工作的通知 [Circular on Activating the Work on Real-name Authentication in Online Games Anti-addiction]. General Administration of Press and Publication of P. R. China. Visited on 24 September 2011, <http://www.gapp.gov.cn/cms/ html/21/508/201108/721032.html>.

11. MOC (2011): 互联网文化管理暂行规定 [Interim Provisions on the Administration of Internet Culture]. Ministry of Culture of P. R. China. Visited on 24 September 2011, <http://www.gov.cn/ flfg/2011-03/21/content_1828568.htm>.

12. MOC (2006): 互联网文化单位进口互联网文化产品内容审查 [Censorship on the Content of Imported Internet Cultural Products for Internet Culture Import Institutes]. Ministry of Culture of P. R. China. Visited on 24 September 2011, <http://www.ccnt.gov.cn/xxfb/zwxx/bszn/ xzxkxm/200610/t20061027_60384.html>.

13. People's Procuratorate of Liangzhong City (2009): 期待审核制度完善 [Expecting the Censorship System to Improve]. Visited on 24 September 2011, <http://www.lzsjcy.gov.cn/ShowArticleA. asp?LanMuID=11\&ID=537>.

14. MOC (2010): 关于改进和加强网络游戏内容管理工作的通知 [Circular on Improving and Strengthening the Management of Online Games Content]. Ministry of Culture of P. R. China. Visited on 24 September 2011, <http://www.cgigc.com.cn/201009/79651832505.html>.

15. State Council of P. R. China [国务院] (2011): 出版管理条例 [The Regulations on Publication Administration]. Visited on 24 September 2011, <http://www.gov.cn/zwgk/2011-03/19/content_1827821.htm>.

16. [出版活动必须坚持为人民服务、为社会主义服务的方向, 坚持以马克思列宁主义、毛泽东思想、 邓小平理论和 ‘三个代表” 重要思想为指导, 贯彻落实科学发展观, 传播和积累有益于提高民族素 质、有益于经济发展和社会进步的科学技术和文化知识, 弘扬民族优秀文化, 促进国际文化交流, 丰富和提高人民的精神生活。]. See note 15 .

17. [(一) 对阐述、传播宪法确定的基本原则有重大作用的; (二) 对弘扬社会主义核心价值体系, 在 人民中进行爱国主义、集体主义、社会主义和民族团结教育以及弘扬社会公德、职业道德、家庭美 德有重要意义的; (三) 对弘扬民族优秀文化, 促进国际文化交流有重大作用的; (四) 对推进文 化创新, 及时反映国内外新的科学文化成果有重大贡献的; (五) 对服务农业、农村和农民, 促进 公共文化服务有重大作用的; (六) 其他具有重要思想价值、科学价值或者文化艺术价值的。]. See note 15 .

18. （一）反对宪法确定的基本原则的; (二) 危害国家统一、主权和领土完整的; (三) 泄露国家秘密、 危害国家安全或者损害国家荣誉和利益的; (四) 煽动民族仇恨、民族歧视, 破坏民族团结, 或者 侵害民族风俗、习惯的; (五) 宣扬邪教、迷信的; (六) 散布谣言, 扰乱社会秩序, 破坏社会稳定 的;（七）宣扬淫秽、奢博、暴力或者教唆犯罪的;（八）侮辱或者诽谤他人, 侵害他人合法权益的; （九）危害社会公德或者民族优秀文化传统的; (十) 有法律、行政法规和国家规定禁止的其他内 容的。]. See note 11 .

19. YANGyU, Boluo (2009): 各级文化部门查处非法网络游戏219多款 [The Culture Department on All Levels Has Investigated and Punished More Than 219 Illegal Online Games]. Visited on 24 September 2011, <http:/game.people.com.cn/GB/48647/175654/175754/10660161.html>.

20. MOC (2009): 文化部办公厅关于立即查处 “黑帮” 主题非法网络游戏的通知 [The Circulation of the General Office of the Ministry of Culture on Investigating and Prosecuting Illegal Internet Games with the Theme of 'Reactionary Gang']. Ministry of Culture of P. R. China. Visited on 24 September 2011, <http://www.mcprc.gov.cn/xxfb/xwzx/whxw/200907/t20090727_72198.html>.

21. Sheng, Lutao and ZHU, Wei (2004): 文化部查处非法电脑游戏《虎胆雄心》[The Ministry of Culture Investigated and Prosecuted Illegal Video Game “Heart of Iron”]. Visited on 24 September 2011, <http://news.xinhuanet.com/newscenter/2004-05/28/content_1496511.htm>.

22. Z HANG, Peng (2005): 总署追查《大战略大东亚兴亡史》游戏 [GAPP investigates the game “Big Stratagem: the History of the Greater East Asia Co-prosperity Sphere II”]. Visited on 24 September 2011, <http://v2002.xwcbj.gd.gov.cn/xwfb/news_brow.asp?id=6263>.

23. Sheng, Lutao and Chen, Fei (2005): 文化部紧急查禁网络游戏《足球经理2005》 [The Ministry of Culture Conducted an Emergency Ban on the Online Game “Football Manager 2005”]. Visited on 24 September 2011, <http://www.china.com.cn/chinese/law/723114.htm>.

24. TANG, Xinyi (2004): 《绿色游戏推荐标准》出台对网游分级 [The Green Games Recommendable Regulation Was Published to Conduct Age-rating on Online Games]. Visited on 24 September 2011, <http://news.xinhuanet.com/game/2004-11/15/content_2220485.htm>. 
25. ZhANG, Han (2010): 文化部回应关网吧提案 [The Ministry of Culture Responded to the Proposal Regarding Shutting down Internet Café]. Visited on 24 September 2011, <http://finance.people. com.cn/GB/11079920.html>.

26. FENG, Hongping and WANG, Feng (2007): 魔兽世界升级, 露骨亡灵长肉 [The Bony Undead have Grown Flesh after World of Warcraft Updated]. Visited on 24 September 2011, <http://www. sinaimg.cn/gm/o/n/2007-06-28/U734P115T9D203365F167DT20070628134733.jpg>.

27. Xinhua News Agency (2007): Skeletons Banned in Chinese 'World of Warcraft.' Visited on 24 September 2011, <http://www.china.org.cn/english/entertainment/216622.htm>.

\section{REFERENCES}

Billiani, Francesca (2007a): Assessing Boundaries: Censorship and Translation. An Introduction. In: Francesca Billiani, ed. Modes of Censorship and Translation. National Contexts and Diverse Media. Manchester: St. Jerome, 1-25.

Billiani, Francesca, ed. (2007b): Modes of Censorship and Translation. National Contexts and Diverse Media. Manchester: St. Jerome.

Brownlie, Siobhan (2007): Examining Self-Censorship. Zola's Nana in English Translation. In: Francesca Billiani, ed. Modes of Censorship and Translation. National Contexts and Diverse Media. Manchester: St. Jerome, 205-234.

Gambier, Yves (2002): Les censures dans la traduction audiovisuelle. TTR. 15(2):203-222.

Kuniwczak, Piotr (2009): Censorship as a Collaborative Project: a Systemic Approach. In: Eiléan Ní Chuilleanáin, Cormac Ó Cuilleanáin and David Parris, eds. Translation and Censorship: Patterns of Communication and Interference. Dublin: Four Courts Press, 46-56.

Merkle, Denise, ed. (2002): Special Issue: Censure et traduction dans le monde occidental / Censorship and Translation in the Western World. TTR. 15(2).

Merkle, Denise, O'Sullivan, Carol, Van Doorslaer, Luc, et al., eds. (2010): The Power of the Pen. Translation \& Censorship in Nineteenth-century Europe. Vienna: Lit-Verlag.

Ní Chuilleanáin, Eiléan, Ó Cuilleanáin, Cormac and Parris, David (2009a): Introduction. In: Eiléan Ní Chuilleanáin, Cormac Ó Cuilleanáin and David Parris, eds. Translation and Censorship: Patterns of Communication and Interference. Dublin: Four Courts Press, 9-23.

Ní Chuilleanáin, Eiléan, Ó Cuilleanáin, Cormac and Parris, David, eds. (2009b): Translation and Censorship: Patterns of Communication and Interference. Dublin: Four Courts Press.

Seruya, Teresa, ed. (2008): Translation and Censorship in Different Times and Landscapes. Newcastle upon Tyne: Cambridge Scholars Publishing.

Түмосzко, Maria (2009): Censorship and Self-Censorship in Translation: Ethics and Ideology, Resistance and Collusion. In: Eiléan Ní ChuILleanáin, Cormac Ó CuILlEanáin and David PARRIS, eds. Translation and Censorship: Patterns of Communication and Interference. Dublin: Four Courts Press, 24-45.

Wolf, Michaela (2002): Censorship as Cultural Blockage: Banned Literature in the Late Habsburg Monarchy. In: Denise Merken, ed. Special Issue: Censure et traduction dans le monde occidental / Censorship and Translation in the Western World. TTR. 15(12):45-61.

ZHANG, Xiaochun (2008): 'Harmonious' games localization for China. MultiLingual. October/ November:47-50. 